\title{
Allometric growth estimation of Prunus armeniaca L. leaves from danyore valley, gilgit-baltistan, Pakistan
}

\begin{abstract}
Apricot, a deciduous, perennial having tree habited species is a member of family Rosaceae. Thousands of poor farmers and their families in the area rely on apricot for their livelihood. Seventy-one countries across the globe produce a total of 3.95million tons of apricot annually. Pakistan stands on 6th and produces 0.178 million-tons. Out of its total more than $60 \%$ comes from Gilgit-Baltistan. Present allometric study of leaves was conducted for the first time. Research revealed that mean leaf width is $7.456 \mathrm{~cm}$, mean length is $8.508 \mathrm{~cm}$ and mean leaf area recorded was $64.82 \mathrm{~cm}^{2}$. On an average leaf reach to its growth climax in a period of $60 \pm 5$ days. In 24 hours times, mean growth in length increase was $14.18 \mathrm{~mm}$ followed by $12.42 \mathrm{~mm}$ in width and $108 \mathrm{~mm}^{2}$ areas. Average height of trees recorded was $11 \mathrm{~m}$ and trunk width at breast height was $40 \mathrm{~cm}$ wide. Large number of land races with unique germ plasm continues to deplete due to mercerization of only a single variety by the government and other organizations. There are more than 40 varieties grown in the area. Strategies are critical to sustain such a great resource of germ plasm.
\end{abstract}

Volume 2 Issue I - 2018

\author{
Khadim S, Khan T, Kiran C,Ali S, Begum Z \\ Department of Biological Sciences, Karakoram International \\ University Gilgit, Pakistan
}

\begin{abstract}
Correspondence: Tika Khan, Department of Biological Sciences, Karakoram International University, Gilgit, GilgitBaltistan, Pakistan, Tel 00923468480360 ,

Email tika.khan@kiu.edu.pk
\end{abstract}

Received: January 05, 2018 | Published: February 21, 2018

Keywords: apricot, karakoram, ethnobotany, leaf area index, apricot verities, gilgit, healthy life, fruit

\section{Introduction}

Prunus Armeniaca L., apricot, is a member of family Rosaceae bears deciduous tree. ${ }^{1}$ Still its origin is unclear among the researchers. In olden times it was known in America, then started to cultivate. ${ }^{2}$ It is assumed that it may have originated in Northeastern China close to the Russian border. According to Morikian $\mathrm{ES}^{3}$ it was known to Armenians which is supported by the discovery of its ancient seeds $\left(6,000\right.$-year-old). Now it is grown in the republic. ${ }^{3}$

It is obtainable and consumed in both fresh as well as dried form. Both have contained equal nutrients. ${ }^{4}$ The apricot (Habi) leaves are ovate, $5-9 \mathrm{~cm}$ long and $4-8 \mathrm{~cm}$ wide, with a rounded base, a pointed tip and a finely serrated margin. Its flowers are $2-4.5 \mathrm{~cm}$ ) in diameter (Figure 1). The fruit is $1.5-2.5 \mathrm{~cm}$ diameter (larger in some modern cultivars), from yellow to orange, then it turns to red mostly sun exposed side. Its surface is glabrous or soft with very short hairs. Its taste can range from sweet to tart. Traditionally apricot has been used for medicinal purposes over the last 2,000years in India, China and Pakistan. The Greeks wrongly assumed that the apricot start off in Armenia; hence its botanical name P. armeniaca. The name apricot evolved from Precocious, referring to the fruit's early ripening. ${ }^{5}$

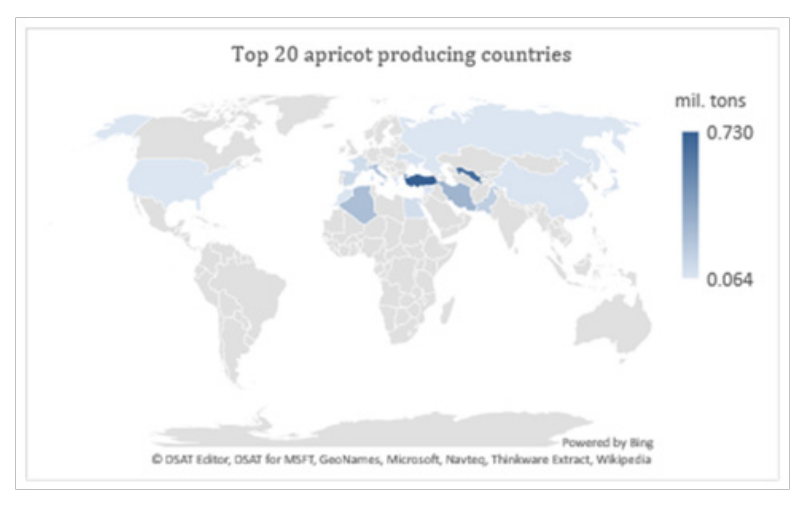

Figure I Top 20 apricot producing countries.
Apricots are used as a rich food source of vitamins and minerals. Apricot kernel is used for cancer treatment however, there is no clinical prove or evidence to cure. Hypersensitivity has been reported. Adverse reactions that are like cyanide poisoning have been reported ${ }^{6}$ Moreover, medicinally apricot is used for asthma, cough, constipation, bleeding, infertility, eye inflammation, spasm, and infections. Furthermore, in manufacturing, apricot oil is used in cosmetics. ${ }^{7}$ Apricots are well-to-do in antioxidants which protect and keep secure our bodies from free radicals and damage to cells and tissues. ${ }^{8}$

Seventy-one countries across the globe produce a total of 3.95 million tons of apricot annually. Pakistan stands on 6th and produces 0.178 million tons. Out of its total more than $60 \%$ comes from Gilgit-Baltistan. Current study was meant to investigate growth estimation of leaves of apricot which is critical to understand as it is the only source to feed fruit and its production (Figure 2).

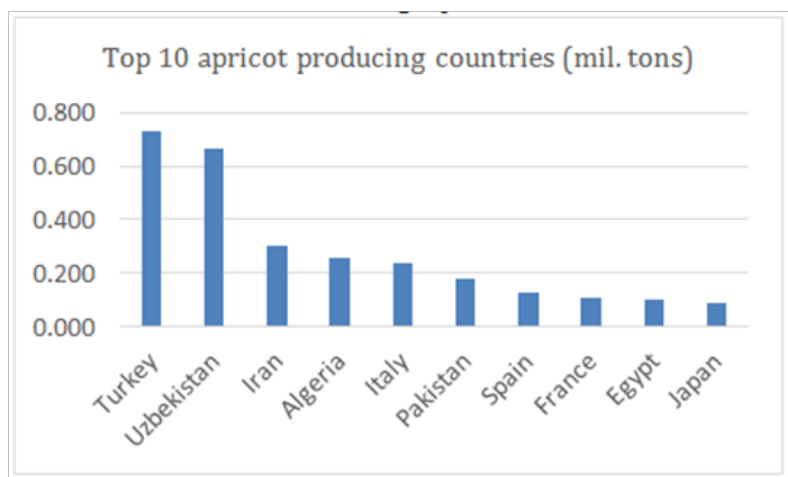

Figure 2 Top 20 apricot producing countries (mil. tons).

\section{Materials and methods}

Prunus armeniaca L., (Common name: HABI) 100 plants were selected from Danyore Valley, district Gilgit, Gilgit-Baltistan, Pakistan. All selected plants were tagged and monitored continuously. Different parameters considered were; height of tree, trunk width 
at breast height, leaf length, leaf width and leaf total area growth. On each week end, parameters were recorded till it stopped to grow further. Ten leaves from each tree were marked and monitored.

\section{Results and discussion}

Research revealed that mean leaf width is $7.456 \mathrm{~cm}$, mean length is $8.508 \mathrm{~cm}$ and mean leaf area recorded was $64.82 \mathrm{~cm}^{2}$. On an average leaf reach to its growth climax in a period of $60 \pm 5$ days. In 24hours times, mean growth in length increase was $14.18 \mathrm{~mm}$ followed by $12.42 \mathrm{~mm}$ in width and $108 \mathrm{~mm}^{2}$ area.

Northern Pakistan harbor great diversity of apricot land races. Thousands of poor families heavily rely on their production, processing and sale for income generation. Growing climate change impacts have introduced new pathogens and diseases. Government agriculture department and other not for profit agencies promote only commercially valuable varieties. This has resulted in the depletion of unique germ plasm. Continued ignorance towards such a loss of important resistant genepool will lead to vulnerability of other commercial varieties. Ultimately this can be harmful for their production, resistance, yield and depletion of livelihood sources of poor farmers. This requires conservation and promotion of all surviving land races for their sustainability. There are more than 40 varieties grown in the area. Strategies are critical to sustain such a great resource of germ plasm.

\section{Acknowledgments}

This study was carried out as part of semester research being conducted during.

\section{Conflict of interest}

Authors declare that there is no conflict of inertest.

\section{References}

1. Wikipedia. Apricot. 2016.

2. Wikipedia. Apricot, the free encyclopedia. 2016.

3. Morikian ES. Apricots of Armenia: Origin and classification of varieties. ISHS Acta Horticulturae 121: VII Symposium on Apricot Culture and Decline. 1983.

4. Kevat D. Apricot Fruit 12 Health Benefits \& Facts You Should Know. Fitness World. 2016.

5. Chevalier A. The Encyclopedia of Medicinal Plants. New York: DK Publishing; 1996. p. 254-255.

6. Drugs. Drugs. 2016.

7. Web MD. Photochemistry of Prunus. 2016.

8. Stylecraze. Health Benefits of Apricot. 2016. 